https://doi.org/10.4316/CC.2020.02.008

\title{
UNIVERSITIES - ACTORS IN CROSS-BORDER COOPERATION BUILDING. STUDY CASE: ROMANIA-UKRAINE BORDER
}

\author{
Marcela ȘLUSARCIUC ID , Gabriela PRELIPCEAN \\ Stefan cel Mare University of Suceava (Romania) \\ E-mails: slusarciuc.marcela@usv.ro; prelipceang@usm.ro
}

\begin{abstract}
The purpose of this paper is to explore different expressions of the universities' involvement in cross-border cooperation across the European countries or international, as a way to strengthen the role in the extended community for the ones near a border. Moreover, it aims to identify specific actions and networks, as good practices where universities are the leading players in building cross-border cooperation. The first part of the research is based on several cases illustrated in scientific literature or promoted directly by different universities in Europe or around the world. At the same time, the second part also uses the official data on cross-border projects, official statements and documents, and the partial results of field research that we did in the cross-border area Romania-Ukraine. Therefore, we found that, in the pursuit of a sustainable path, universities found various ways to anchor in networks among themselves or with community actors. The ones near the border used the incentives offered by the cross-border programmes to build long-term partnerships and good practices in the benefit of the academia and also of the community.
\end{abstract}

Keywords: universities, cross-border cooperation, partnership, sustainability, multiculturalism, Romania, Ukraine.

Rezumat: Universitățile - actori în construirea cooperării transfrontaliere. Studiu de caz: granița România-Ucraina. Scopul acestei lucrări este de a explora diferite expresii ale implicării universităților în cooperarea transfrontalieră în țările Europei sau la nivel internațional, ca modalitate de consolidare a rolului în comunitățile extinse pentru cele aflate în apropierea frontierei. În plus, lucrarea își propune să identifice acțiuni și rețele specifice, ca bune practici în care universitățile sunt principalii jucători în construirea cooperării transfrontaliere. Prima parte a cercetării se bazează pe diverse cazuri ilustrate în literatura științifică sau promovate direct de diferite universități din Europa sau din lume, iar în partea a doua sunt utilizate date oficiale despre proiecte transfrontaliere, declarații și documente oficiale, precum și rezultate parțiale ale unei cercetări de teren pe care am realizat-o în zona transfrontalieră România-Ucraina. Prin urmare, am identificat existența posibilității ca, în căutarea unei căi sustenabile, universitățile au găsit variate moduri de a se ancora în 
rețele între ele sau împreună cu actori din comunitate, iar cele din apropierea frontierei au utilizat stimulentele oferite de programele de cooperare transfrontalieră pentru a construi parteneriate pe termen lung și bune practici în beneficiul academic și al comunitătii.

\section{INTRODUCTION}

In the frame of continuous and updated promotion of the territorial cooperation inside the European Union (EU) and friendly neighbourhood relation with the partner countries, the cross-border collaboration was activated in different forms along the time. There are mainly two approaches: by the Council of Europe - the soft approach through policy papers and Euroregions, and European Union - the more in-depth approach through policies, regulations and programmes that finance projects with a mandatory cross-border partnership. The already traditional role of the universities as poles of a regions' development was extended, if we consider the communities along a common border as a region with a shared history, culture or traditions.

The purpose of this paper is to explore different expressions of the universities' involvement in cross-border cooperation (CBC) across the European countries or international, as a way to strengthen the role in the extended community for the ones near a border, and to identify specific actions and networks. In these as good practices, universities are the leading players in building cross-border cooperation.

For a proper understanding of the paper, we would like to review some of the concepts and frames that are part of the core of our research. Local communities and authorities living along borders face challenges and issues originating from the presence of the state frontier, fact that showed during the time an effective solving of such problems involves the development of joint cross-border approach and strategy. Therefore, the essence of cross-border initiatives is to overcome the peripheral positioning of border areas.

The term 'cross-border cooperation' has several different scientific and political definitions. One of the earliest bases for the concept of cross-border cooperation was established in the European Outline Convention on Transfrontier Cooperation between Territorial Communities or Authorities, Article 2: "For the purpose of this Convention, transfrontier cooperation shall mean any concerted action designed to reinforce and foster neighbourly relations between territorial communities or authorities within the jurisdiction of two or more Contracting Parties and the conclusion of any agreement and arrangement necessary for this purpose. Transfrontier cooperation shall take place in the framework of territorial 
communities' or authorities' powers as defined in domestic law."1. The European Union (EU) institutions apply this term with the meaning of cooperation among regions near the border to foster the integrated regional development and to tackle common problems through the implementation of joint initiatives, programmes and projects across borders. As we notice, even if the Council of Europe uses the term 'transfrontier cooperation', basically it has the same meaning as the one used by the EU institutions. Both it refers to cooperation on a regional level between communities divided by an international border.

In the EU approach, the cross-border cooperation is one of the various forms of territorial cooperation. The latter is a broad term referring to any horizontal cooperation at a subnational or regional level between local communities, regions and/or cities. The purpose of the territorial cooperation to reduce disparities between areas, to strengthen cohesion and to foster local economic and social development. There are considered three primary forms of territorial cooperation in the EU: transnational cooperation, interregional cooperation and cross-border cooperation. Transnational cooperation relates to large connected areas of several countries and involves national, regional and local actors that, in collaboration, tackle at a particular issue. Interregional cooperation operates at a pan-European level and includes collaboration between regional and local authorities based on exchanging of experiences, information and best practices. It could also refer to cooperation between remoted regions or networking between many areas ${ }^{2}$.

In a unifying approach, we can use the definition promoted by the Crossborder cooperation toolkit. "Cross-border cooperation (CBC) is a concerted process of building neighbourly relationships between local stakeholders and authorities on either side of a border, intending to overcome such problems and foster the harmonious development of neighbouring communities. Its success should be built on clear concrete objectives and the willingness to cooperate." 3

Additionally, we refer to the cross-border regions (CBR) that are territorial units who participate in territorial cooperation and include CBC initiatives. These are also defined as a regions with common geography, history, economic possibilities, culture, but crossed by state borders. They act as 'playground' for the actors

${ }^{1}$ Council of Europe, European Outline Convention on Transfrontier Co-operation between Territorial Communities or Authorities European, Madrid, Treaty Series - 106, 1980.

2 Rafal Sadowski, E-Platform for Neighbourhood, 2017 (retrieved from http://www.euforneighbourhood.eu/e-platform/e-learning-platform/, accessed on 01.03.2020).

${ }^{3}$ Centre of Expertise for Local Government Reform, Council of Europe, Crossborder Cooperation Toolkit, 2012 (retrieved from http://slg-coe.org.ua/wp-content/uploads/ 2012/10/Toolkit_Cross-border-co-operation.pdf, accessed on 01.03.2020). 
involved, including universities.

Still, in some of the references and examples we found, the authors or the actors involved use a broader sense for cross-border cooperation, as across the borders, more appropriate to transnational cooperation concept. We accept those cases as relevant for the role of universities beyond the one within national borders, as creating the flows for education, knowledge, research, therefore added value. Most of the universities are also connected with other universities in the neighbourhood, across the border. Therefore, the benefits of being part of a transnational network significantly contributes to the $\mathrm{CBC}$ and the regional development of CBR.

The second set of information that should be reminded for a better understanding of the paper is related to the frame of CBC programmes. These represent the main incentive that drawn the universities in the Romania-Ukraine border into the CBC. Moreover, these funds acted as the seed for long term cooperation and for autonomous initiatives, beyond the grants supplied by CBC programmes.

When launching of the Cohesion Policy in 1988, the European Communities considered the need to mitigate disparities on a regional level, as a strengthening of the regional development approach, and created the context for $\mathrm{CBC}$ to emerge as an instrument for fostering regional development and cohesion with European and subnational influence. In the current state, there is CBC inside the EU's territory, as part of European Territorial Cooperation, which is part of Cohesion Policy, and $\mathrm{CBC}$ with EU direct neighbours. For the latter, it can be distinguished two groups of neighbours - those in the process of accession to the EU or with an EU's membership perspective, and those with whom the EU just develops partnership relations. In the case of the $\mathrm{CBC}$ inside the EU's territory, the focus is mainly on the economic and social cohesion. In contrast, in the case of the EU's external CBC programmes, the priority is related to maintaining security at European borders by fostering prosperity and deepening economic and social ties between the EU and non-EU actors.

Even if there are several programmes targeted to the relation with neighbours, we will focus on the ones with an EU's membership perspective, as Ukraine is included in this group. A first programme, which aimed to support candidate countries' border areas through CBC with EU regions was a PHARE-CBC Programme established for Central Europe in 1994. The programme intended to reduce the marginalisation of border areas mainly through the implementation of infrastructure schemes and programmes stimulating economic development, while also intended to prepare the concerned regions to join Cohesion Policy and 
Interreg programme after they had become EU members. In the case of the Romania-Ukraine border, there was Romania-Ukraine Neighbourhood Programme 2004-2006, and the programme was implemented until 2010. The programme was replaced by the European Neighbourhood and Partnership Instrument (ENPI) in 2007, and it was followed by the European Neighbourhood Instrument (ENI) in 2014. Both instruments were established in order to support the implementation of the European Neighbourhood Policy (ENP). The policy encompasses all 16 EU's neighbours in the east and south. The ENPI and the ENI include CBC programmes, for the Romania-Ukraine border we consider: the Joint Operational Programme (JOP) Romania-Ukraine-Republic of Moldova and JOP Hungary-Slovakia-Romania-Ukraine (for 2007-2013), and the JOP Romania-Ukraine and JOP Hungary-Slovakia-Romania-Ukraine (for 2014-2020).

\section{UNIVERSITIES INVOLVEMENT IN CROSS-BORDER COOPERATION: SCIENTIFIC LITERATURE AND EMPIRICAL EXAMPLES}

In this section, we present several cases of cross-border activity of universities as proofs of varieties or forms of involvement, with no assessment on efficiency or effectiveness, while it is not the purpose of the paper.

In our endeavour of review of few cases that illustrate the involvement of universities in $\mathrm{CBC}$, we mention two provisions of policy approach. The first provision refers to inclusion of the development of education, research and innovation, and innovative communication technologies in the EU's Common Strategic Framework of the Common Provision Regulation document. The long-term aim is to improve the competitiveness of small and medium enterprises as the core of territorial cooperation (it includes the cross-border, transnational and interregional cooperation). ${ }^{4}$ It proves the vital place of education and research in the cross-border cooperation and the opportunity for the universities to play a significant role in CBR. The second provision gives orientation on possible activities that may be developed by universities in the educational field in the CBR: universities twinning, exchanges and cross-border visits, awareness campaigns on the neighbouring communities languages, history and culture in university programmes, arrangement of bilingual teaching programmes, access to university across the border, establishment of cross-border educational entities, programmes and/or

${ }^{4}$ European Parliament and the Council, Regulation (EU) No 1303/2013 laying down common provisions on the European Regional Development Fund, the European Social Fund, the Cohesion Fund, the European Agricultural Fund for Rural Development, Bruxelles, 2013. 
curricula, mutual accreditation systems. Both provisions give a policy encouraging background for universities involvement in CBC.

As mentioned above, we found in literature cases where the cross-border concept is wider perceived with a more substantial transnational dimension. One is a specific approach of cross-border education that ease access and promote innovation and responsiveness of higher education, constituted as a movement of education programs and providers, that needs to be structured and regulated ${ }^{5}$. A similar case is one outside EU, but an exciting illustration of possible actions, the Cross-border Education Research Team (C-BERT) that designed a Hub for Crossborder Education as the source of information regarding college and universities with a multi-national presence. The site is hosted at the State University of New York at Albany and Pennsylvania State University and maintains a comprehensive list of international branch campuses and also tracks other aspects of cross-border higher education ${ }^{6}$. The third is focused on the cross-border university networks as a development strategy with a possibility to develop longer-term activities which would exceed the capacity of the individual institution and would promote more sustainable relationships than twinning projects between universities $^{7}$. In this paper, the authors study three cases of multi-university networks, one in Africa and two in Asia, their experiences showing that networks can be a useful mechanism to promote a social and educational agenda in parallel with the capacity strengthening of involved universities.

Going on the specific meaning of cross-border cooperation, we found several cases, both in literature and in the online platforms of different universities across EU member states. An example is the European University Viadrina, located on the German-Polish border, founded to promote the 'growing-together' of Europe. The case of Viadrina University serves as an example of how to facilitate intercultural competence by a course programme, giving the possibility to students to experience, discover and discuss the diversity of values and worldviews in special workshops ${ }^{8}$. In another paper, a group of researchers reviewed several

${ }^{5}$ Jane Knight, Crossborder Education: Not Just Students, 2015 (retrieved https://ejournals.bc.edu/index.php/ihe/article/download/7499/6693/, accessed on 01.03.2020).

${ }^{6}$ C-BERT.org, Hub for Crossborder Education, Crossborder Education Research Team, 2019 (retrieved from www.c-bert.org, accessed on 01.03.2020).

${ }^{7}$ David W. Chapman, Amy Pekol, Elizabeth Wilson, Crossborder university networks as a development strategy: Lessons from three university networks focused on emerging pandemic threats, "International Review of Education", 2014, Issue 60, p. 619-637.

${ }^{8}$ Gundula Gwen Hiller, Maja Woźniak, Developing an intercultural competence programme 
cases on inter-university cooperation at the external border of EU and the contribution to the ENP, detecting several results and potential on both border sides and marked the opportunity of the university networks to open the borders in a figurative sense ${ }^{9}$. Based on a previous work on development poles with cross-border potential, we identified that the universities are important centres in a partnership network for cross-border regions ${ }^{10}$. They play a significant role in local/regional clusters and part of a theoretical frame ${ }^{11}$, reason for us including aspects related to universities in our recent field research. Part of the results are described in the next section of the paper.

We extended our investigation for examples of universities involvement in CBC across Europe by looking at some of their websites, and we found several ways of contributing to the cross-border cooperation. We do a short presentation of few of them that we considered relevant to consider, trying to group the cases on education, research or general networking, depending on how the main focus is, as presented online. In the field of education, we identified a Joint Master in Borderology, initiated by Bodø University, Norway, in partnership with Murmansk State Technical University, Russia. As the site presents, the study programme "explores how collaboration in border zones can develop tools for solving conflicts locally, nationally and globally - thereby creating a new type of international dialogue largely neglected in traditional state diplomacy". Usually, the seminars are held in Northern Norway and the Murmansk-region, Russia (Nord University, 2018).12 In the area of research, we found more examples with a different structure or form of organisation. A first example is the International Boundaries Research Unit (IBRU) founded in 1989 as part of the Geography Department at

at an international cross-border university, "Intercultural Education", 2009, 20(1), pp. 113-124.

${ }^{9}$ Sorin Şipoş, Mircea Brie, Florin Sfrengeu, Ion Gumenâi, Cooperarea inter-universitară la frontierele externe ale Uniunii Europene și contribuţia la politica europeană de vecinătate [Inter-university cooperation at the external borders of the European Union and contribution to the European Neighborhood Policy], in "Frontierele spaţiului românesc în context European”, Oradea/Chişinău: Editura Universităţii din Oradea/ Editura Cartdidact, 2008, pp. 440-459.

10 Marcela Slusarciuc, Noi arhitecturi ale polilor de dezvoltare cu potențial transfrontalier. București, Ed. Didactică și Pedagogică, 2016

11 Marcela Slusarciuc, Gabriela Prelipcean, Clusters - a potential model of development for crossborder areas, "Romanian Journal of Economics”, 2014, 2(48), pp. 148-160.

12 Nord University, Borderology - Joint Master Degree, 2018 (retrieved from https://www.nord.no/en/studies/borderology-master\#\&acd=StudyAbroadHeader, accessed on 01.03.2020). 
Durham University. It is designed as a Centre for Borders Research and "seeks to facilitate enhanced understanding of border areas, contribute to the peaceful resolution of boundary disputes, and engage with broader geographic questions concerning the changing nature of sovereignty, territory, citizenship, and the political organisation of space". ${ }^{13}$ A different example is EconPol Europe - a European network for economic and fiscal policy research that includes 14 policy-oriented university and non-university research institutes across 12 countries. They have a contribution in scientific expertise to the discussion of the future design of the European Union. Their topics cover: sustainable growth, best practices, reform of EU policies, the EU budget, capital markets, the regulation of the financial sector, governance, and macroeconomic policy in the European Monetary Union. $1{ }^{14} \mathrm{~A}$ case with a conflictual context where the university involvement in cross-border cooperation was strongly needed is represented by the Centre for cross-border studies. It was created in the context of the island of Ireland conflict mitigation in the frame of the Belfast/Good Friday Agreement. As they present on the website, the Centre has a role in contributing to the increased social, economic and territorial cohesion of the island of Ireland. They issued different high-quality research and analysis, with an increased focus on applied research and policy, that should support the Centre's advocacy for the promotion of cross-border cooperation on the island of Ireland..$^{15} \mathrm{~A}$ different case that we consider relevant, even if it is not a university but a research entity, it is Cross-border Research Association, CBRA, formally established in Lausanne, Switzerland in 2005, as an independent research institute that works on domains as: advanced supply chain security, crime prevention, risk management, trade facilitation, cross-border trade and logistics, and public-private cooperation research, training and consulting. As presented on their website, they made several key trade facilitation studies, as for example: Improving the Border Agency Cooperation Among the OIC Member States for Facilitating Trade (2016), commissioned by the Secretariat of the Standing Committee for Economic and Commercial Cooperation (COMCEC) of the Organisation of Islamic Cooperation (OIC); and The Import VAT and Duty De-Minimis in the European Union - Where Should They be and What Will be the Impact? (2014), study mandated

\footnotetext{
${ }^{13}$ Durham University, IBRU - International Borders Research Unit, 2019 (retrieved from https://www.dur.ac.uk/ibru/, accessed on 01.03.2020).

${ }^{14}$ EconPol Europe, EconPol Europe, 2017 (retrieved from https://www.econpol.eu/ index.php).

${ }^{15}$ Centre for Crossborder Studies, Centre for Crossborder Studies, 2019 (retrieved from http://crossborder.ie/, accessed on 01.03.2020).
} 
by the European Express Association (EEA), Belgium. ${ }^{16}$ The interest on cross-border research is not only in Europe, as illustrated by Cross-border Institute at the University of Windsor, dedicated to research, education, and public outreach related to the movement of people, goods, and funds across borders. As stated in their online page, they have a partnership with public agencies, private firms, industry groups and community groups. They advance the cause of making a better Canada - US border and they also work with institutions in other countries to address the global challenges of border management and cross-border commerce. ${ }^{17}$ In Romania, we found the Cross-border Institute of International Studies and Criminal Justice, throughout the Centre for International Studies and Human Rights. Their stated objectives are to promote performant applied and fundamental research, to establish a link between academic researchers and practitioners of international law, political studies, international relations and human rights, economics and public administration, regional and security studies. The center is set up by "Dunărea de Jos" University of Galați, and they issue the Cross-border Journal of International Studies. The journal has a transdisciplinary approach, focused on tackling neuralgic points of cross-border cooperation in the globalised international society, aiming to analyse a series of issues specific to the area and the EU external border region. We found no proofs of recent activity to detect if they are still in place. ${ }^{18}$

The example we consider the most complex out of the ones we found is the University of the Greater Region (2016). This is a network of six universities (the University of Kaiserslautern, the University of Liège, the University of Lorraine, the University of Luxembourg, Saarland University and Trier University). They are located on the cross-border area of the Greater Region (Germany - Rhineland-Palatinate and Saarland; Belgium - Wallonia, French and German communities of Belgium; France Grand-Est Region /Lorraine, Grand Duchy of Luxembourg). As the information on their page, this is "a cooperation project bringing together six universities in four countries to improve the mobility of students, researchers and teachers, enriching courses and research profiles, while enhancing the reputation and attractiveness of the partner universities and the region". In terms of figures they state, the network

${ }^{16}$ Crossborder Research Association, Crossborder Research Association, 2014 (retrieved from www.crossborder.org, accessed on 01.03.2020).

${ }^{17}$ Crossborder Institute, Crossborder Institute at the University of Windsor, 2019 (retrieved from www.cbinstitute.ca, accessed on 01.03.2020).

18 Dunărea de Jos University of Galați, The Crossborder Institute for International Studies and Criminal Justice, 2017 (retrieved from http://www.cbinstitute.ugal.ro/, accessed on 01.03.2020). 
includes more than 135.000 students, near $7.000 \mathrm{PhD}$ candidates, more than 10.000 lecturers and researchers, and they use three teaching languages (French, German, English) offering good mobility to all within the network. ${ }^{19}$

\section{RESEARCH METHODOLOGY}

On the border we investigate, Romania-Ukraine, the CBR includes on the Romanian side five administrative units (counties): Satu Mare, Maramureș, Suceava, Botoșani, Tulcea; and on the Ukrainian side - four administrative divisions (oblasts): Zakarpattia, Ivano-Frankivsk, Chernivtsi, Odesa. A map of the CBR may be seen in Figure 1.

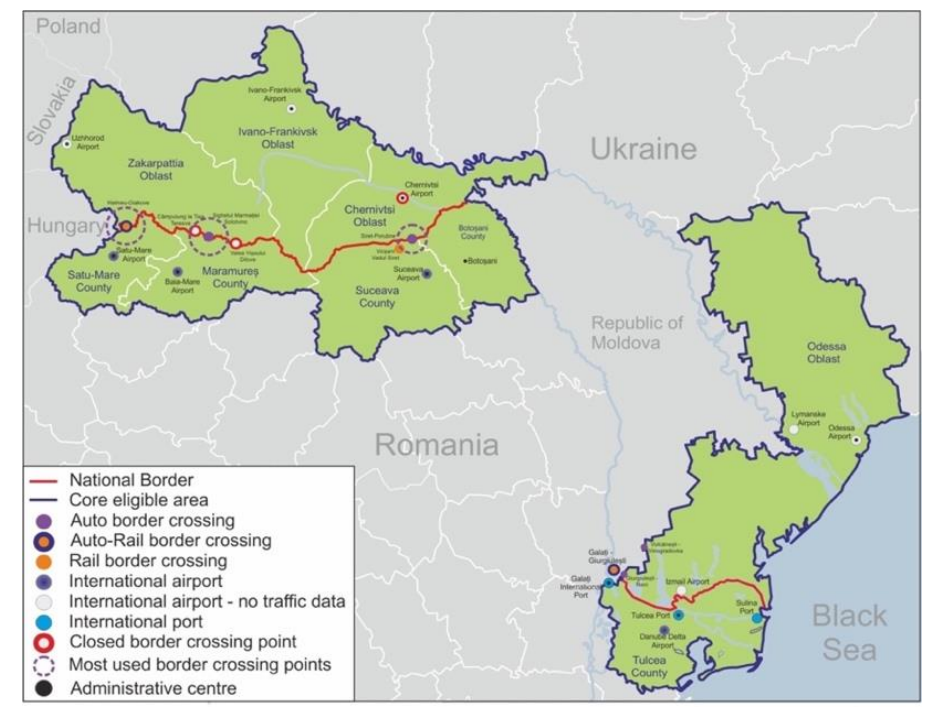

Figure 1: Map of the Cross-border region Romania-Ukraine

Source: Joint Operational Programme Romania-Ukraine 2014-202020

In our work, we used three categories of data. The first ones are the data on the projects approved within $\mathrm{CBC}$ programmes where the universities are leaders or partners. The second category include the data collected on the field, where a questionnaire was applied with two questions related to the university involvement in the CBR. The third category is represented by data about different CBC events or other types of activities promoted in the media or on the universities'

\footnotetext{
${ }^{19}$ University of the Greater Region, University of the Greater Region, 2016 (retrieved from www.uni-gr.eu, accessed on 01.03.2020)

${ }^{20}$ Managing Authority Romania, Joint Operational Programme Romania-Ukraine 20142020, 2015 (retrieved from www.ro-ua.net, accessed on 01.03.2020)
} 
websites. In the following, we describe each type of used data.

In the investigated region, the first relevant $\mathrm{CBC}$ programme was Neighbourhood Programme Romania-Ukraine 2004-2006 that had four calls for proposals and ended in 2010 . The projects had a mandatory partnership between Romanian and Ukrainian non-profit entities, but the leadership, the budget and activities management were on the Romanian partner ${ }^{21}$. The eligible area was the one described above as the research area for our paper. The second generation of programmes was 2007-2013 when the border was split: JOP Romania-UkraineRepublic of Moldova (Romania: 3 counties - Suceava, Botoșani, Tulcea, Ukraine: 2 oblasts - Chernivtsi, Odesa), JOP Hungary-Slovakia-Romania-Ukraine (Romania: 2 counties - Satu Mare, Maramureș, Ukraine: 2 oblasts - Zakarpattia, Ivano-Frankivsk). In this generation, the partnership was also mandatory. Still, the conditions differed from one programme to another. For JOP Romania-Ukraine-Republic of Moldova it was compulsory to have a Romanian entity (as Romania was the only member state in the programme). In the case of JOP Hungary-Slovakia-RomaniaUkraine it was mandatory to have a Ukrainian entity (as Ukraine was the only partner country in the programme). The leadership could be on any of the sides; the budget and activities were shared among partners. The programmes ended in 2018. The third generation, the actual one is 2014-2020, where the eligible area went back to bilateral JOP Romania-Ukraine. The partnership is mandatory as in the first generation, and the application, team, budget and activities should be jointly prepared and managed. In the case of the last programme, there was only one call for proposals, and the results are not published yet. Therefore, we do not have official data on the universities' involvement, but only on the types of activities, they could apply for grants.

The field data are from a survey conducted in spring 2018, with the support of Regional Office for Cross-border Cooperation Suceava, as the questionnaire was applied to potential applicants of JOP Romania-Ukraine 2014-2020 that attended the information events organised in the border area. The questionnaire had several questions, most of them open, and was returned by 124 respondents, out of which 58 Romanians and 66 Ukrainians. Regarding the structure of the respondents and issues of representativity, the following tables show the distribution of respondents as a type of entity and coverage of the administrative units from Romania and Ukraine (Table 1 and Table 2).

${ }^{21}$ Marcela Slusarciuc, Financial instruments for crossborder economic development. Shaping the new tendencies at the european level - PhD thesis, Suceava, Universitatea Ștefan cel Mare, 2013. 
Table 1: The number of respondents per type of entity

\begin{tabular}{l|c}
\hline Type of entity & No. of respondents \\
\hline Local Public Administration & 46 \\
\hline Regional Public Administration & 6 \\
\hline University & 14 \\
\hline Business Organisations & 0 \\
\hline Firms & 3 \\
\hline Non-governmental organisations & 32 \\
\hline Other Public Institutions & 23 \\
\hline Total & $\mathbf{1 2 4}$ \\
\hline
\end{tabular}

Source: Own calculation.

Table 2: The number of respondents in each administrative unit

\begin{tabular}{c|c|c|c}
\hline $\begin{array}{c}\text { Administrative unit } \\
\text { Romania }\end{array}$ & $\mathbf{5 8}$ & $\begin{array}{c}\text { Administrative unit } \\
\text { Ukraine }\end{array}$ & $\mathbf{6 6}$ \\
\hline Satu Mare & 12 & Zakarpattia & 12 \\
\hline Maramures & 11 & Ivano Frankivsk & 9 \\
\hline Suceava & 16 & Chernivtsi & 36 \\
\hline Botosani & 8 & Odesa & 9 \\
\hline Tulcea & 11 & & \\
\hline
\end{tabular}

Source: Own calculation.

The questionnaire was structured on different issues, and it was applied both in Romanian and Ukrainian language. The two questions of interest for our paper are one dichotomic (yes/no/no answer) and one open, namely: 'Does your institution/organisation cooperate with the university/universities in the area?' and 'If yes, name the university/universities and the cooperation fields.' It is significant to mention, as not to lead to inaccurate interpretation of data presented that it could be more respondents from the same entity. The questionnaire was distributed to events with no limitations regarding the participants from one entity where we had no control on the distribution or collection of questionnaires.

The last type of data was focused on identifying if there are any other CBC activities besides the ones granted within the CBC programmes, where the universities are involved. As there is no centralised information, we considered that the universities own activities promoted on their websites or through general media would be an input. In the cases we found, we noticed that the same information was also reflected on the universities' websites and media or on the websites of more universities in cases where more universities are involved. Therefore, we 
decided to use as reference just one source, regardless in how many sources there is the information. Relevant for our paper is the type of activities as qualitative information and not the quantitative information related to the $\mathrm{CBC}$ activities awareness in the public space.

\section{RESULTS AND DISCUSSION}

The CBC programmes were a useful "incentive package" to encourage cooperation among communities along the border for all the potential applicants, not only universities. Those programmes were designed to act specifically on the needs of the communities along the border, in a subsidiarity manner. On the other side, the universities have complementary access EU programmes where can strengthen or enlarge the cooperation with the partners on the other side of the border (for example, Erasmus - previous and actual format, research programmes - FP7 or Horizon 2020). In the earlier generations, even if the steps were smaller, but it was built trust and shared knowledge by the partners involved 22 .

The domains for projects where the universities were potential applicants changed across generations as we can compare in the table below (Table 3).

Table 3: Project domains where universities were potential applicants in different generations of CBC programmes

\begin{tabular}{|c|c|c|c|}
\hline $\begin{array}{c}\text { CBC pro- } \\
\text { grammes } \\
\text { generation }\end{array}$ & 2004-2006 & 2007-2013 & $2014-2020$ \\
\hline $\begin{array}{l}\text { Domains eli- } \\
\text { gible for uni- } \\
\text { versities }\end{array}$ & $\begin{array}{l}\text { Economy and } \\
\text { tourism } \\
\text { Infrastruc- } \\
\text { ture } \\
\text { Environment } \\
\text { People to } \\
\text { people ac- } \\
\text { tions }\end{array}$ & $\begin{array}{l}\text { Economic and so- } \\
\text { cial development } \\
\text { Environment qual- } \\
\text { ity including emer- } \\
\text { gency prepared- } \\
\text { ness } \\
\text { Border safety } \\
\text { People to people }\end{array}$ & $\begin{array}{l}\text { Education and research } \\
\text { Culture, patrimony and herit- } \\
\text { age } \\
\text { Accessibility - transport and } \\
\text { ICT tools } \\
\text { Safety and security - Health is- } \\
\text { sues, emergency preparedness, } \\
\text { organised crime and police co- } \\
\text { operation }\end{array}$ \\
\hline
\end{tabular}

Source: Own work based on the programming documents. ${ }^{23}$

22 Ibidem.

${ }^{23}$ Joint Managing Authority Romania, Joint Programming Document, 2006 (retrieved from http://www.mie.ro/_documente/cbc/2004_2006/RoUa/programare/JPD\%20update d\%20final.pdf, accessed on 01.03.2020); Joint Operational Programme Romania- 
We notice that, if in the case of the first two generations of programmes the domains were general for an university, the capability of applying depending on the universities' fields of education and research, in the case of the actual generation there is a specific priority on education and research that gives an important opportunity for all the universities from CBR to develop partnerships and to cooperate on educational projects or research projects, regardless the academic field of interest.

In our search on the data available on the programmes websites we found several lists with the concluded contracts, and we identified on those lists the universities from Romania-Ukraine CBR, as defined previously, that were acting as leaders or partners in CBC projects. Even if in the case of the 2007-2013 generation there were more universities involved due to the larger eligibility area (JOP Hungary-Slovakia-Romania-Ukraine and JOP Romania-Ukraine-Republic of Moldova cover an eligible area larger than the area we refer in our research) we selected only the ones in our RT. As we already mentioned, for the actual generation JOP Romania-Ukraine was not informing yet the evaluation results, therefore we do not have data. Still, we have the data for the actual JOP Hungary-Slovakia-Romania-Ukraine, which had already two calls for proposals, where we count only the projects and universities from our area of interest.

Table 4: Involvement of universities from Romania-Ukraine CBR in CBC projects

\begin{tabular}{c|c|c|c|c}
\hline $\begin{array}{c}\text { CBC pro- } \\
\text { gramme } \\
\text { generation }\end{array}$ & $\begin{array}{c}\text { No. of univer- } \\
\text { sities in- } \\
\text { volved in CBC } \\
\text { projects }\end{array}$ & $\begin{array}{c}\text { No. of projects } \\
\text { with universi- } \\
\text { ties involved }\end{array}$ & $\begin{array}{c}\text { No. of projects } \\
\text { where univer- } \\
\text { sities are } \\
\text { leaders }\end{array}$ & $\begin{array}{c}\text { No. of projects } \\
\text { where univer- } \\
\text { sities are } \\
\text { partners }\end{array}$ \\
\hline $2004-2006$ & 2 & 7 & 7 & 0 \\
\hline $2007-2013$ & 9 & 12 & 7 & 9 \\
\hline $2014-2020$ & 5 & 6 & 4 & 5 \\
\hline
\end{tabular}

Source of data: for 2004-2006 - www.mdrap.ro/www.brctsuceava.ro; for 2007-2013 www.huskroua-cbc.net and www.ro-ua-md.net; for 2014-2020 - www.huskroua-cbc.eu

Ukraine-Republic of Moldova. People, partnerships and development: ENPI CBC Romania-Ukraine-Republic of Moldova, Suceava, BRCT Suceava, 2016; Joint Managing Authority Hungary, Joint Operational Programme Hungary-Slovakia-Romania-Ukraine, 2008 (retrieved from http://www.huskroua-cbc.net/uploads/editors/JOP-HUSKROUA\%2030092014-amended_final.pdf); Managing Authority Romania, JOP RomaniaUkraine 2014-2020, 2015 (retrieved from www.ro-ua.net, accessed on 01.03.2020). 
As mentioned in the methodology section, in case of 2004-2006 only the Romanian entities were leaders of the project and we have no data about the partners from Ukraine as to check if there are any universities involved. Anyway, the role of Ukrainian partners was mainly formal and had less real involvement in the projects, only as participants. As for 2014-2020, we have only partial data we cannot compare with the previous generation at this time. We can notice that, since the shared management and budget (2007-2013 and 2014-2020), universities are involved not only in projects with some other universities but in projects where the leaders are different type of entity, fact that proves the role of the universities as an actor in the local/regional CBC network.

Related to the above, the perspective of universities included in partnership in the community with other actors, not only other universities, we present the data from the field research, resulted from the questionnaire application as described in the methodology section.

Out of all respondents, $61 \%$ cooperate with universities from their area, on the same side or the other side of the border, as illustrated below (figure no. 2). We consider that it could be interpreted as a sign of the importance of universities as actors in the local community.

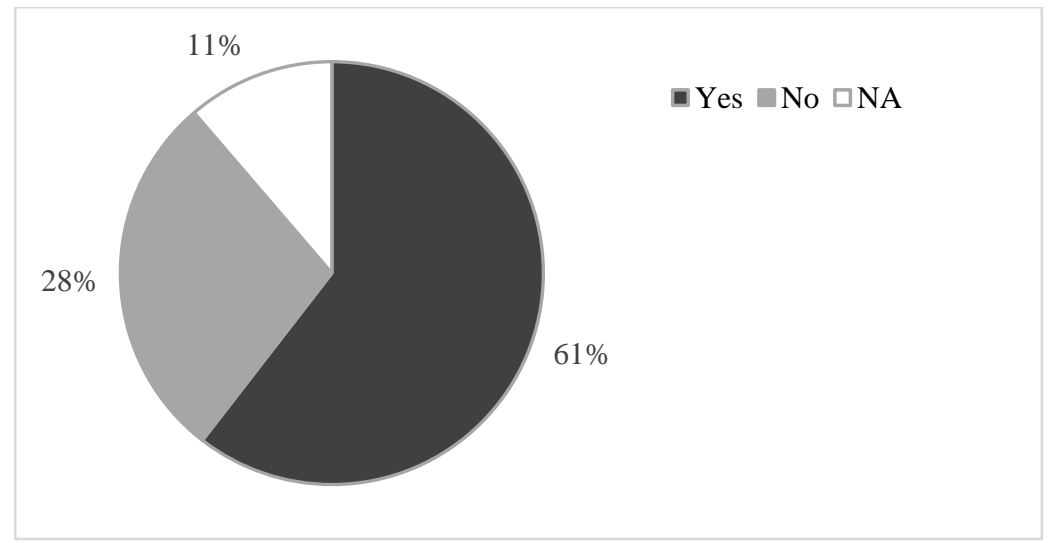

Figure 2: Cooperation with universities in the CBR

Source: Own calculation.

As we can see in the table below (Table 5), the respondents cooperate with the universities from their administrative unit, with universities outside the border area but in neighbouring administrative units or with their branches located in the border region. Not all the respondents that mentioned existing cooperation with a university also named it, and other respondents named more than one university with which they cooperate, on their side of the border or the other side. 
Table 5: Named university by the respondents as a cooperation partner in the community (*number of respondents)

\begin{tabular}{|c|c|}
\hline \multicolumn{2}{|c|}{ Romanian respondents } \\
\hline Romanian university & Ukrainian university \\
\hline $\begin{array}{l}\text { “Al. I. Cuza” Univ. Iasi (1)* } \\
\text { “Babes Bolyai” Univ. Cluj Napoca (2) } \\
\text { “Danubius” Univ. Galati (3) } \\
\text { “Dunarea de Jos” Univ. Galati (5) } \\
\text { Stefan cel Mare Univ. of Suceava (11) } \\
\text { North Univ. Baia Mare (1) } \\
\text { Technical Univ. - Univ. Centre North - } \\
\text { Baia Mare (6) } \\
\text { West Univ. "Vasile Goldis" Arad - Satu } \\
\text { Mare, Baia Mare branches (5) }\end{array}$ & $\begin{array}{l}\text { "Yuryi Fedkovych" Univ. Chernivtsi (3) } \\
\text { State Univ. of Izmail (2) } \\
\text { Univ. of Gas and Petrol Ivano Frankivsk (1) } \\
\text { National Univ. Uzhhorod (3) } \\
\text { National Polytechnical Univ. of Odesa (3) }\end{array}$ \\
\hline \multicolumn{2}{|c|}{ Ukrainian respondents } \\
\hline Romanian university & Ukrainian university \\
\hline $\begin{array}{l}\text { Stefan cel Mare Univ. of Suceava (2) } \\
\text { "Babeş-Bolyai" Univ. din Cluj-Napoca } \\
\text { (1) } \\
\text { West Univ. "Vasile Goldis" Arad (1) }\end{array}$ & $\begin{array}{l}\text { Odesa National Academy of Food Technolo- } \\
\text { gies (2) } \\
\text { Construction College Storojineț (1) } \\
\text { Pedagogic and Psychology Institute of the } \\
\text { Pedagogic National Univ. M. P. Dragomanov } \\
\text { Kiev (2) } \\
\text { Storojineț Institute of State Fiscal Service Na- } \\
\text { tional Univ. (2) } \\
\text { Agrarian National Univ. Odesa (1) } \\
\text { Human Development Univ. "Ucraina" - } \\
\text { Storojineț Branch } \\
\text { Medical State Univ. Bukovina Chernivtsi (10) } \\
\text { Open Univ. for Adults Chernivtsi (1) } \\
\text { Economic Univ. Odesa (3) } \\
\text { National Univ." I. Mechnickov" Odesa (1) } \\
\text { National Medical Univ. Ivano-Frankivsk (1) } \\
\text { National Univ. of Forestry Lviv (1) } \\
\text { "Yuryi Fedkovych" Univ. Chernivtsi (12) } \\
\text { "Vasyl Stefanyk" Precarpathian National } \\
\text { Univ. (4) } \\
\text { Univ. of Gas and Petrol Ivano-Frankivsk (3) } \\
\text { National Univ. Uzhhorod (5) } \\
\text { National Polytechnical Univ. of Odesa (1) } \\
\text { Univ. of seniors (1) }\end{array}$ \\
\hline
\end{tabular}


The results show an adequate involvement of the universities in their community near the border, the higher cooperation with the universities from the country of respondents is no surprise. The methodological aspects of the survey do not give enough room to conclude that Romanian entities cooperate more with Ukrainian universities rather than reversed. We have no additional information to connect and have a clear conclusion. Thus, it is easy to notice that on the Ukrainian part of CBR there are more universities and branches than on the Romanian part. Thus, we can conclude that there is a potential of networking for universities in the CBR, both with other universities and local/regional entities.

After two closed generations of CBC programmes, we notice that the exercise of partnership and cooperation between the universities from the RomaniaUkraine border area generated other initiatives for cooperation beside those programmes with the financial incentive. In a sketchy search on the universities' websites and some media channels, we found several examples and forms of initiatives out of which we resume some of them.

The larger representativeness as coverage of universities is in case of consortiums that act as networks with a core agreement. An example is Consortium Collegium Carpathicum that includes six members. Two of them are from Poland: East European State University in Przemysl and Warsaw University. Hungary, Slovakia, Romania and Ukraine have each one university in the network (Catholic University Pazmany Peter of Budapest, Presov University, Sttefan cel Mare University of Suceava - USV, National Precarpathian University "Vasyl Stefanyk" IvanoFrankivsk. Besides at least yearly meetings, they have constant professors and lecturers' exchanges in various fields. Another one is Consortium of the Universities of the Republic of Moldova-Romania-Ukraine (the State University of Moldova, "Alecu Russo" University Bălți, "Al. I. Cuza" University Iași, Stefan cel Mare University of Suceava, Arts University "George Enescu" Iași, National University "Yuriy Fedkovych" Chernivtsi) that started in 2011 and had several activities along years: Romanian language lectorate of USV to National University "Yuriy Fedkovych" Chernivtsi, yearly meetings, educational projects development, research projects, artistic projects, students joint activities.

An interesting tool for promoting CBC in the area is represented by specialised academic programmes, as we also seen in the cases from the first section; therefore, it worth to mention the master studies in International Relation and Cross-border Cooperation held by Ștefan cel Mare University of Suceava for several years already. We can also add here the Summer Schools for students 
from neighbourhood countries, organised yearly and in association with national partners too. ${ }^{24}$

Another case of involvement alongside the local/regional actors in the CBR development is through debates concerning the common topics. We found the example of the Center for European Studies of the "Al. I. Cuza" University, who organised a discussion with the topic "University in society. Development and integration at EU's borderlines by dialogue and knowledge exchange". They intended to stimulate the interactivity between academic, non-governmental organisations, groups of experts, and decision-makers. The aim was to better connect in the cross-border area and to increase of awareness on the RomaniaUkraine and Romania-Republic of Moldova CBC programmes opportunities. The participants covered Euroregions, local and regional administration, cross-border cooperation offices, universities from the border area and non-governmental organisations from the border area. ${ }^{25}$ Even if the initiative was outside CBR Romania-Ukraine, the inclusion of relevant actors and the exchange of experiences is suitable for our research area too.

For the cases where Euroregions are still active, and universities are included in the main stakeholders' group, they can play a useful role and support the governance within the Euroregion as a structured way for manifesting crossborder cooperation. We have the example of "Upper Prut" Euroregion, where, in a duplex meeting Suceava-Chernivtsi, attended the universities in the area with the relevant stakeholders in an endeavour to strengthen the role of the first one in the area. They promoted two types of specific activities: preparation of studies in the region as to identify the potential for new clusters starting or extension of existing ones, together with preparation of several studies as service offered to the local/regional stakeholders, and development of a Cross-border research centre that would promote knowledge, provide specialised assistance in developing strategies or projects designed for the region or local communities. ${ }^{26}$

The last example of initiative with impact on cross-border cooperation in the Romania-Ukraine area and with universities' involvement is through projects financed by other programmes. It is the case of Jean Monnet Network ENACTED -

24 Stefan cel Mare University of Suceava, Universitatea Stefan cel Mare Suceava, 2019 (retrieved from www.usv.ro, accessed on 01.03.2020).

25 Al. I. Cuza University, "Al. I. Cuza" University, 2019 (retrieved from www.uaic.ro, accessed on 01.03.2020).

${ }^{26}$ Stefan cel Mare University of Suceava, Universitatea Ștefan cel Mare Suceava, 2019 (retrieved from www.usv.ro, accessed on 01.03.2020). 
European Union and its neighbourhood. Network for enhancing EU's actorness in the eastern borderlands (2017-2020), which associates research, lectures, debates on the EU role on the Eastern borders in a type of open academic network that brings together twelve partners, out of which nine are universities, mostly from border areas: "Al. I. Cuza" University of Iași, University of Oradea, Stefan cel Mare University of Suceava, Academy of Economic Studies of the Republic of Moldova, State University of the Republic of Moldova, "Yuriy Fedkovych" University Chernivtsi, State University Belarus, School of Economic Sciences Warsaw, Poland; University of Debrecen, Hungary. ${ }^{27}$

As a sum-up of the various data used and our perspective, we notice that there are several forms of partnership/cooperation that universities may use. The main forms are represented by research projects, CBC bilateral or multilateral projects, networks among universities, networks among actors in the CB region. Several types of activities put in practice the cooperation: events, academic exchanges of experience, students mobilities, students joint events, specialised training programmes on cooperation abilities, specialised educational programmes for undergraduates, master or $\mathrm{PhD}$, studies for regional strategies. All forms can contribute to the cross-border cooperation and development of CBR.

The involvement of universities in CBC brings benefits as a share of knowledge, awareness of the other, cooperative approach building on a long term, capitalisation of various existent experiences, all necessary for a sustainable university that is marked by the peripherality due to near the border location. It needs a different type of data and research tools to investigate on a long term the manifest of the mentioned benefits and contribution to adjusting in a new frame of development for CBR.

\section{CONCLUSIONS}

The cases and data presented show good practices as examples of how universities, especially the ones in the CBR, in a sustainable approach, can connect and build projects, partnerships and networks, among them and with the local/regional actors. The bases started with the by CBC programmes incentives through grants and developed further in separate initiatives that explore

${ }^{27}$ Al. I. Cuza University, "Al. I. Cuza" University, 2019 (retrieved from www.uaic.ro, accessed on 01.03.2020). 
other sources for funds and different innovative ways to make use of the advantages of cross-border location. Therefore, we found that, in the pursuit of a sustainable path, universities found various ways to anchor in academic networks or community networks. The ones near the border used the incentives offered by the CBC programmes to build long-term partnerships and good practices in the benefit of the academic field and the community field. The various forms of partnership/cooperation that universities use, and the types of activities contribute to the CBC and development of CBR, due to the benefits that bring. It worth to mention the share of knowledge, awareness of the other, cooperative approach on a long term, capitalisation of various existent experiences. On long term strengthen the universities to face shortcomings caused by the location near the border. Future in-depth research may include a complex sustainability index to measure the border (including economic) impact of CBC activities (education, research, and cooperation projects) of the universities located near the border, regardless the network of actors they are part universities or community.

\section{BIBLIOGRAPHY:}

1. Al. I. Cuza University, "Al. I. Cuza" University, 2019, (retrieved from www.uaic.ro).

2. C-BERT.org, Hub for Cross-border Education, Cross-border Education Research Team, 2019 (retrieved from www.c-bert.org).

3. Centre for Cross-border Studies, Centre for Cross-border Studies, 2019 (retrieved from http://cross-border.ie).

4. Centre of Expertise for Local Government Reform, Council of Europe, Cross-border Cooperation Toolkit, 2012 (retrieved from http://slg-coe.org.ua/wp-content/uploads/2012/10/Toolkit_Cross-border-co-operation.pdf).

5. Chapman W. David, Pekol Amy, Wilson Elizabeth, Crossborder university networks as a development strategy: Lessons from three university networks focused on emerging pandemic threats, "International Review of Education", 2014, Issue 60, p. 619-637.

6. Council of Europe, European Outline Convention on Transfrontier Co-operation between Territorial Communities or Authorities European, 1980, Madrid, Treaty Series - 106.

7. Cross-border Institute, Cross-border Institute at the University of Windsor, 2019 (retrieved from www.cbinstitute.ca).

8. Cross-border Research Association, Cross-border Research Association, 2014 (retrieved from www.cross-border.org). 
9. Dunărea de Jos University of Galați, The Cross-border Institute for International Studies and Criminal Justice, 2017 (retrieved from http://www.cbinstitute.ugal.ro/).

10. Durham University, IBRU - International Borders Research Unit, 2019 (retrieved from https://www.dur.ac.uk/ibru/).

11. EconPol Europe, EconPol Europe, 2017 (retrieved from https://www.econpol.eu/index.php).

12. European Parliament and the Council, Regulation (EU) No 1303/2013 laying down common provisions on the European Regional Development Fund, the European Social Fund, the Cohesion Fund, the European Agricultural Fund for Rural Development, Bruxelles, 2013.

13. Hiller Gundula Gwen, Woźniak Maja, Developing an intercultural competence programme at an international cross-border university, "Intercultural Education", 2009, 20(1), pp. 113-124.

14. Joint Managing Authority Hungary, Joint Operational Programme Hungary-SlovakiaRomania-Ukraine, 2008 (retrieved from http://www.huskroua-cbc.net/uploads/editors/JOP-HUSKROUA\%2030092014-amended_final.pdf).

15. Joint Managing Authority Romania, Joint Programming Document, 2006 (retrieved from http://www.mie.ro/_documente/cbc/2004_2006/RoUa/programare/JPD\%20 updated\%20final.pdf).

16. JOP Romania-Ukraine-Republic of Moldova, People, partnerships and development: ENPI CBC Romania-Ukraine-Republic of Moldova, 2016, Suceava, BRCT Suceava.

17. Knight Jane, Cross-border Education: Not Just Students, 2015 (retrieved from https://ejournals.bc.edu/index.php/ihe/article/download/7499/6693/).

18. Managing Authority Romania, JOP Romania-Ukraine 2014-2020, 2015 (retrieved from www.ro-ua.net).

19. Nord University, Borderology - Joint Master Degree, 2018 (retrieved from https://www.nord.no/en/studies/borderology-master\#\&acd=StudyAbroadHeader).

20. Sadowski Rafal, E-Platform for Neighbourhood, 2017 (retrieved from http://www.euforneighbourhood.eu/e-platform/e-learning-platform/).

21. Şipoş Sorin, Brie Mircea, Sfrengeu Florin, Gumenâi Ion, Cooperarea inter-universitară la frontierele externe ale Uniunii Europene şi contribuţia la politica europeană de vecinătate [Inter-university cooperation at the external borders of the European Union and contribution to the European Neighborhood Policy], in Frontierele spaţiului românesc în context European" Oradea/Chişinău: Editura Universităţii din Oradea/ Editura Cartdidact, 2008, pp. 440-459.

22. Slusarciuc Marcela, Financial instruments for cross-border economic development. Shaping the new tendencies at the European level - PhD thesis, Suceava, Universitatea "Ștefan cel Mare", 2013.

23. Slusarciuc Marcela, Noi arhitecturi ale polilor de dezvoltare cu potențial transfrontalier [New architectures of development poles with cross-border potential], București, Ed. Didactică și Pedagogică, 2016. 
24. Slusarciuc Marcela, Prelipcean Gabriela, Clusters - a potential model of development for crossborder areas, "Romanian Journal of Economics", 2014, 2(48), pp. 148-160.

25. Ștefan cel Mare University of Suceava, Universitatea Ștefan cel Mare Suceava, 2019 (retrieved from www.usv.ro).

26. University of the Greater Region, University of the Greater Region, 2016 (retrieved from www.uni-gr.eu). 